\title{
PENGARUH MODEL KOOPERATIF TIPE THINK-PAIR-SHARE (TPS) TERHADAP KEMAMPUAN PENYELESAIAN MASALAH DAN DISPOSISI MATEMATIS DITINJAU DARI KEMAMPUAN AWAL SISWA SMP SWASTA ISLAM DI TANGSEL
}

\author{
Venni Herli Sundi ${ }^{1{ }^{*}}$, Pinta Deniyanti Sampoerno ${ }^{2)}$, Lukman El Hakim ${ }^{3)}$ \\ ${ }^{1,2,3)}$ Pascasarjana Universitas Negeri Jakarta, 13220 \\ *vennysundi@gmail.com
}

\begin{abstract}
Abstrak
Penelitian ini dilatar belakangi kemampuan penyelesaian masalah siswa yang masih rendah serta ketertarikan, minat, dan sikap positif siswa terhadap matematika yang kurang, sehingga penelitian ini bertujuan untuk mengetahui pengaruh model pembelajaran kooperatif tipe Think-Pair-Share (TPS) terhadap kemampuan penyelesaian masalah matematis dan disposisi matematis siswa. Metode penelitian yang digunakan pada penelitian ini adalah quasi eksperimen. Desain yang digunakan adalah factorial design $2 x 2$ by level. Teknik pengumpulan data menggunakan instrumen tes untuk mengukur kemampuan penyelesaian masalah dan angket untuk mengukur disposisi matematis. Analisis data menggunakan ANAVA dua jalur dan uji-t dengan taraf signifikansi 0,05. Hasil penelitian menunjukkan bahwa (1) kemampuan penyelesaian masalah siswa yang belajar menggunakan model kooperatif TPS lebih tinggi daripada model pembelajaran konvensional, (2) terdapat interaksi antara model pembelajaran dan kemampuan awal matematika terhadap kemampuan penyelesaian masalah matematis siswa, (3) terdapat perbedaan kemampuan penyelesaian masalah matematis antara siswa dengan kemampuan awal matematika tinggi yang belajar dengan model kooperatif TPS dan model pembelajaran konvensional,(4) disposisi matematis siswa yang belajar dengan model pembelajaran kooperatif TPS lebih tinggi dari pada model pembelajaran konvensional, (5) terdapat interaksi antara model pembelajaran dan kemampuan awal matematika terhadap disposisi matematis siswa,(6) terdapat perbedaan kemampuan disposisi matematis antara siswa dengan kemampuan awal matematika tinggi yang belajar dengan model pembelajaran kooperatif TPS dan model pembelajaran konvenisonal.
\end{abstract}

Kata Kunci: Pembelajaran Kooperatif Tipe TPS, Kemampuan Penyelesaian Masalah Matematis, Disposisi Matematis.

\section{PENDAHULUAN}

Matematika merupakan salah satu mata pelajaran yang harus dipelajari di pendidikan dasar dan menengah yang ada di Indonesia. Sebagai bahan pelajaran di sekolah, matematika secara khusus memiliki tujuan pembelajaran yang diatur dalam Peraturan Menteri Pendidikan Nasional (Permendiknas) Nomor 22 Tahun 2006 tentang Standar Isi. Turmudi (2008) 
mengungkapkan bahwa pembelajaran matematika yang efektif memerlukan pemahaman apa yang siswa ketahui dan perlukan untuk dipelajari, kemudian memberikan tantangan dan dukungan kepada mereka agar siswa dapat belajar dengan baik. Data dari TIMSS (The Third International Mathematics and Science Study) 2011, menunjukkan bahwa rata-rata skor perolehan pada mata pelajaran matematika berada pada urutan bawah. Indonesia menduduki peringkat 38 dari 45 negara dengan skor 386 dari skor international 613 pada mata pelajaran matematika secara keseluruhan.

Tabel 1. Tingkatan/Level Kinerja Siswa Yang Mengukur Domain Konten Pengetahuan, Penerapan, dan Penalaran.

\begin{tabular}{|c|c|c|}
\hline No & Tingkatan/Level & Skor \\
\hline 1 & $\begin{array}{l}\text { Standar Internasional } \\
\text { Mahir } \quad \text { (advanced } \\
\text { international } \\
\text { benchmark) }\end{array}$ & 625 \\
\hline 2 & $\begin{array}{l}\text { Standar International } \\
\text { Tinggi } \quad \text { (high } \\
\text { international } \\
\text { benchmark) }\end{array}$ & 550 \\
\hline 3 & $\begin{array}{l}\text { Standar International } \\
\text { Tinggi } \quad \text { (high } \\
\text { international } \\
\text { benchmark) }\end{array}$ & 475 \\
\hline 4 & $\begin{array}{l}\text { Standar International } \\
\text { Rendah } \\
\text { international } \\
\text { benchmark) }\end{array}$ & 400 \\
\hline
\end{tabular}

Hasil studi yang dilakukan PISA (Programme for International Student Asessment) 2012 tidak jauh berbeda dengan hasil TIMSS 2011, Indonesia mendapat peringkat ke 64 dari 65 negara peserta dengan hasil rata-rata nilai yang didapat hanya 375 jauh dibawah nilai rata-rata internasional PISA yang mencapai 500 (PISA, 2012). Berdasarkan hasil studi TIMSS 2011 dan PISA 2012 menunjukkan bahwa kemampuan penyelesaian masalah siswa di Indonesia rendah. NCTM (2000) menjelaskan bahwa penyelesaian masalah memegang peranan penting dalam matematika dan harus memegang peranan penting dalam pendidikan matematika.

Penyelesaian masalah merupakan bagian dari kurikulum matematika yang sangat penting. Sependapat dengan pernyataan tersebut, dalam buku Yusuf, (2014) Lencher mendefinisikan penyelesaian masalah matematika sebagai proses menerapkan pengetahuan matematika yang telah diperoleh sebelumnya ke dalam situasi baru yang belum dikenal. National Council of Teachers of Mathematics (NCTM) (1989) menjelaskan bahwa penyelesaian masalah merupakan proses yang melingkupi seluruh bagian progam pembelajaran matematika serta menyediakan keterampilan berbentuk konteks berkonsep. Memnu,. Hart dan Akkaya (2012) menyatakan kemampuan penyelesaian masalah tidak dapat dikembangkan hanya dengan beberapa minggu atau bulan saja. Polya (2004) yang mendefinisikan penyelesaian masalah sebagai usaha mencari jalan keluar dari suatu kesulitan. Polya menyusun prosedur menyelesaikan masalah dalam empat langkah yang digunakan dalam penelitian ini, yaitu: (a) Pemahaman Masalah (understanding the problem), (b) Menemukan Suatu Rencana (devising a plan), (c) Melaksanakan Rencana (carry out the plan), (d) Memeriksa Kembali (looking back).

Pembelajaran matematika tidak hanya berkaitan tentang pembelajaran konsep, prosedural, dan aplikasinya, tetapi juga terkait dengan pengembangan minat dan 
keterkaitan terhadap matematika yang powerful. Pengembangan minat dan keterkaitan terhadap matematika tersebut akan membentuk kecenderungan yang kuat yang dinamakan disposisi matematis (mathematical disposition). Sumarmo (2012) mendefinisikan disposisi matematis sebagai suatu keinginan, kesadaran, dedikasi dan kecenderungan yang kuat pada diri siswa untuk berpikir dan berbuat secara matematik dengan cara yang positif dan didasari dengan iman, taqwa, dan akhlak mulia. White, Murray, dan Vega (2012) Disposisi adalah kebiasaan pikiran termasuk atribut kognitif dan afektif yang menyaring pengetahuan, keterampilan, dan kepercayaan seseorang dan mempengaruhi tindakan yang dilakukan seseorang di kelas atau pengaturan profesional. Kilpatrick et al (2001) menjelaskan bahwa disposisi matematik disebut juga productive disposition (sikap produktif), yakni tumbuhnya sikap positif serta kebiasaan untuk melihat matematika sebagai sesuatu yang logis, berguna dan berfaedah. Cooke (2015) meyakini bahwa penggunaan komponen untuk menjelaskan disposisi terhadap matematika sama dengan pendekatan yang digunakan untuk menyelidiki dampak emosi terhadap hasil literasi kuantitatif.

Indikator disposisi matematis yang digunakan dalam penelitian ini mencakup: a) rasa percaya diri dalam menggunakan matematika, memecahkan masalah, memberi alasan, dan mengkomunikasikan gagasan, b) fleksibilitas dalam menyelidiki gagasan matematik dan berusaha mencari metoda alternatif dalam memecahkan masalah c) tekun mengerjakan tugas matematik, d) minat, rasa ingin tahu (curiousity), dan daya temu dalam melakukan tugas matematika, e) cenderung memonitor, mereplesikan performance dan penalaran mereka sendiri, f) menilai aplikasi matematika ke situasi lain dalam matematika dan pengalaman sehari-hari, g) apresiasi (appreciation) peran matematika dalam kultur dan nilai, matematika sebagai alat dan bahasa.

Siswa kurang percaya diri dalam menggunakan matematika untuk dapat menyelesaikan masalah, mengkomunikasikan ide-ide matematis dan memberikan argumentasi. Hal inilah yang menyebabkan rendahnya kemampuan siswa dalam menyelesaikan masalah dan kurangnya disposisi matematis siswa. Salah satu model pembelajaran yang dimungkinkan dapat meningkatkan kemampuan penyelesaian masalah dan disposisi matematis adalah model pembelajaran kooperatif tipe Think-PairShare (TPS). Arends (1997) mengemukakan TPS pertama kali dikembangkan oleh Frang Lyman dan koleganya di Universitas Maryland dan menyatakan bahwa TPS merupakan suatu cara yang efektif untuk membuat variasi suasana pola diskusi kelas. Menurut Kurniasi (2015) model pembelajaran TPS atau berpikir berpasangan adalah jenis pembelajaran kooperatif yang dirancang untuk mengatur pola interaksi siswa. Tint, San San and Ei Ei Nyunt (2015) menyatakan berpikir, berpasangan dan berbagi adalah kegiatan yang mendorong siswa untuk merenungkan masalah dan kemudian berbagi pemikiran dengan orang lain. Chianson, Mimi Martha (2015) Mengemukakan TPS merupakan strategi pembelajaran yang melibatkan siswa dengan materi pelajaran tingkat individu, berpasangan dan akhirnya sebagai kelompok besar.

Hamdayana (2014) mengemukakan model pembelajaran tipe TPS terdiri atas lima langkah, dengan tiga langkah utama 
sebagai ciri khas, yaitu tahap

(1) pendahuluan: awal pembelajaran dimulai dengan penggalian apesiasi sekaligus memotivsi siswa agar terlibat pada aktivasi pembelajaran, (2) think: siswa diminta untuk membaca materi pelajaran yang ada dibuku paket, kemudian siswa diberi batasan waktu (think time) oleh guru untuk memikirkan jawabannya secara individual terhadap pertanyaan yang diberikan, (3) pair: guru mengelompokkan siswa secara berpasangan, (4) share: siswa dapat mempresentasikan jawaban secara perseorangan atau secara kooperatif kepada kelas sebagai keseluruhan kelompok, (5) pengahargaan: siswa mendapat penghargaan berupa nilai baik secara individu maupun kelompok.

Terdapat faktor lain yang dapat memengaruhi kemampuan penyelesaian masalah matematis dan disposisi matematis, yaitu faktor kemampuan awal. Jonassen dan Gabrowski (1993) mendefinisikan kemampuan awal sebagai "pengetahuan, keterampilan, atau kemampuan yang dibawa siswa ke dalam proses belajar. Reigeluth (1999) menjelaskan kemampuan awal merupakan seluruh kompetensi pada level bawah (sub tugas-tugas) yang seharusnya telah dikuasai sebelum siswa memulai suatu rangkaian pembelajaran khusus untuk mengerjakan kompetensi di atas kemampuan awal.

\section{METODE PENELITIAN}

Populasi penelitian ini adalah seluruh siswa SMP Muhammadiyah 44 Pamulang dan SMP Muhammadiyah 22 Setia Budi Pamulang. Sampel penelitian yaitu kelas VIII SMP Muhammadiyah 44 yang terdiri dari 3 rombongan belajar, dan kelas VIII SMP Muhammadiyah 22 Setia Budi Pamulang yang terdiri dari 4 rombongan rombongan belajar pada masing-masing sekolah akan diacak untuk menjadi kelas eksperimen dan kelas kontrol. Kelas eksperimen dan kelas kontrol ditentukan dengan mengunakan nilai UAS semester ganjil 2017/2018. Nilai UAS tersebut dilakukan uji prasyarat yaitu uji normalitas dan uji homogenitas, kemudian melakukan uji kesamaan rata-rata untuk menguji kesetaraan sampel penelitian. Subyek yang digunakan pada penelitian ini sebanyak 144 siswa yang berasal dari 4 kelas. Penelitian dilaksanakan pada semester genap tahun pelajaran 2017/2018. Perlakuan pembelajaran dilakukan sebanyak 9 kali pertemuan, dengan satu kali pertemuan untuk tes kemampuan awal matematika, 7 kali pertemuan proses pembelajaran, dan satu kali pertemuan untuk tes akhir penyelesaian masalah matematika dan disposisi matematis siswa.

Metode yang digunakan dalam penelitian ini yaitu metode eksperimen semu (quasi eksperiment) dengan pengambilan sampel dilakukan dengan teknik multistage sampling. Sampel yang dipilih dikategorikan dalam dua kelompok, yaitu kelompok eksperimen dan kelompok kontrol. Kelompok eksperimen diberi perlakuan menggunakan model pembelajaran kooperatif tipe Think Pair Share (TPS), sedangkan kelompok kontrol diberi perlakuan menggunakan model pembelajaran langsung.

Desain penelitian yang digunakan dalam penelitian ini adalah factorial design $2 \times 2$ treatment by level untuk tiap desain dengan empat variabel. Variabel-variabel tersebut terdiri atas satu variabel bebas yaitu model pembelajaran, dua variabel terikat yaitu penyelesaian masalah matematika dan disposisi matematis siswa dan satu variabel kontrol yaitu kemampuan awal matematika yang terbagi menjadi 
kemampuan awal matematika tinggi dan kemampuan awal matematika rendah.

Instrumen tes penyelesaian masalah matematika, disposisi matematis, dan kemampuan awal matematika divalidasi oleh beberapa pakar, kemudian dihitung validasi isi, validasi empiris dan reliabilitas. Teknik analisis data yang digunakan dalam penelitian ini adalah analisis kovarian dua jalur (anava dua jalur) setelah dilakukan uji prasyarat, meliputi uji normalitas menggunakan uji Kolmogorof Smirnov dan uji homogenitas menggunakan uji Barlett.

\section{Uji Normalitas}

Sujarweni (2014) uji normalitas bertujuan untuk mengetahui distribusi data dalam variabel yang akan digunakan dalam penelitian. Data yang baik dan layak digunakan dalam penelitian adalah data yang memiliki distribusi normal. Pengujian normalitas data pada penelitian ini menggunakan metode KolmogorovSmirnov. Kadir (2016:147) menjelaskan langkah-langkah untuk menguji normalitas data menggunakan metode KolmogorovSmirnov dengan bantuan SPSS-23 pada taraf signifikan $\alpha=0,05$. Kriteria pengujian:

$$
\begin{aligned}
& \mathrm{H}_{0} \text { : data berdistribusi normal } \\
& \mathrm{H}_{1} \text { : data tidak berdistribusi normal }
\end{aligned}
$$

Tabel 2. Uji Normalitas Teknik Pengambilan Sampel (KolmogorovSmirnov)

\begin{tabular}{c|c|c|c|c}
\hline Kelas & $\mathbf{n}$ & Statistic & Df & Sig. \\
\hline VIII 1 & 44 & 0,130 & 36 & 0,129 \\
\hline VIII 2 & 44 &, 100 & 36 &, $200^{*}$ \\
\hline VIII 1 & 22 &, 109 & 36 &, $200^{*}$ \\
\hline VIII 2 & 22 &, 117 & 36 &, $200^{*}$ \\
\hline VIII 3 & 22 &, 137 & 36 &, 086 \\
\hline VIII 4 & 22 &, 103 & 36 &, $200^{*}$ \\
\hline
\end{tabular}

$\mathrm{H}_{0}$ diterima jika sig > 0,05 maka $\mathrm{H}_{0}$ ditolak, jika sig $<0.05$ maka $\mathrm{H}_{0}$ diterima. Berdasarkan uji Kolmogorov Smirnov maka seluruh sampel kelas memiliki nilai sig > 0.05 , sehingga seluruh kelas berdistribusi normal.

\section{Uji Homogenitas}

Uji homogenitas dilakukan setelah data persyaratan normalitas terpenuhi, yakni data dinyatakan berdistribusi normal. Pengujian homogenitas dengan menggunakan uji Barlett melalui SPSS-22 pada taraf signifikan $\alpha=0,05$. Kriteria pengujian:

$$
\begin{aligned}
& \mathrm{H}_{0} \text { : variansi populasi homogen } \\
& \mathrm{H}_{1} \text { : variansi populasi tidak homogen }
\end{aligned}
$$

Tabel 3. Uji Homogenitas (Lavene)

\begin{tabular}{rrrr}
\hline Statistic & \multicolumn{1}{c}{ df1 } & \multicolumn{1}{c}{ df2 } & \multicolumn{1}{c}{ Sig. } \\
\hline 1,790 & 6 & 245 &, 102 \\
\hline
\end{tabular}

Pada tabel di atas diperoleh nilai Sig. $=0,102$. Nilai tersebut lebih besar dari pada nilai $\alpha=0,05$. Karena nilai Sig. $>\alpha$, maka H0 diterima. Dengan demikian, hasil pengujian dengan Levene's statistik tes menggunakan SPSS 22 tersebut menandakan bahwa sampel mempunyai variansi yang sama.

\section{Uji Kesamaan Rata-rata}

Uji kesamaan rata-rata sampel digunakan uji anava satu jalur. Data yang diuji dalam kesamaan rata-rata adalah nilai UAS ganjil dari kelas yang berdistribusi normal dan mempunyai varian yang sama. 
Tabel 4. Uji Kesamaan Rata-Rata

\begin{tabular}{c|c|c|c|c|c}
\hline & $\begin{array}{c}\text { Sum } \\
\text { of } \\
\text { Squar } \\
\text { es }\end{array}$ & df & $\begin{array}{c}\text { Mea } \\
\mathbf{n} \\
\text { Squ } \\
\text { are }\end{array}$ & F & $\begin{array}{c}\text { Sig } \\
\cdot\end{array}$ \\
\hline $\begin{array}{c}\text { Betw } \\
\text { een }\end{array}$ & 316,20 & 6 & 52,7 &, 3 &, 9 \\
$\begin{array}{c}\text { Grou } \\
\text { ps }\end{array}$ & 6 & & 01 & 32 & 20 \\
\hline $\begin{array}{c}\text { Withi } \\
\text { n }\end{array}$ & 38898, & 2 & 158, & & \\
$\begin{array}{c}\text { Grou } \\
\text { ps }\end{array}$ & 222 & 5 & 768 & & \\
\hline Total & 39214, & 2 & & & \\
\hline & 429 & 1 & & & \\
\hline
\end{tabular}

Berdasarkan tabel di atas sig $0,920>0,05$ maha $\mathrm{H}_{0}$ diterima berarti sampel memiliki kesamaan rata-rata. Setelah dilakukan uji normalitas, uji homogenitas dan uji kesamaan ratarata dipilih masing-masing dua kelas sebagai kelompok eksperimen dan sebagai kelompok kontrol, kemudian kedua kelompok tersebut diberikan tes kemampuan awal matematika untuk menentukan kemampuan awal matematika tinggi dan kemampuan awal matematika rendah. Kemampuan awal matematika tinggi dan kemampuan awal matematika rendah diambil dengan cara simple random sampling dengan cara menentukan $33 \frac{1}{3} \%$. Nilai kemampuan awal matematika diurutkan dari yang tertinggi sampai terendah, untuk nilai $33 \frac{1}{3} \%$ urutan teratas dijadikan sebagai siswa dengan kemampuan awal matematika tinggi dan $33 \frac{1}{3} \%$ urutan terbawah dijadikan sebagai siswa dengan kemampuan awal matematika rendah. Pada penelitian ini tidak diambil kemampuan awal matematika sedang dikarenakan untuk melihat pengaruh dan agar ada selisih kemampuan yang diukur. Sampel yang digunakan adalah kelas VIII1 dan VIII2 SMP Muhammadiyah 44 Pamulang sebagai kelas eksperimen, kelas VIII2 dan VIII4 SMP Muhammadiyah 22 Pamulang sebagai kelas kontrol.

Berdasarkan hasil pengambilan sampel, siswa kemudian dikelompokkan menjadi dua kategori yaitu siswa dengan kemampuan awal matematika tinggi dan siswa dengan kemampuan awal matematika rendah, sehingga tidak semua siswa dalam kelas tersebut menjadi subyek penelitian. Kemudian dari masing-masing kelompok tersebut diberikan post-test kemampuan penyelesaian masalah dan pengisian angket disposisi matematis sehingga diperoleh hasil dalam 4 kelompok yang akan dilihat kemampuan disposisi matematis dan peningkatan kemampuan penyelesaian masalah matematis.

Tabel 5. Deskripsi Statistika Hasil Kemampuan Awal Matematika Siswa

\begin{tabular}{cccc}
\hline & \multirow{2}{*}{ Data } & \multicolumn{2}{c}{ Kelas } \\
\cline { 2 - 4 } & Statistik & $\begin{array}{c}\text { Eksperime } \\
\text { n }\end{array}$ & Kontro \\
& & $\mathbf{~}$ & $\mathbf{N}$ \\
\cline { 2 - 4 } KA & $\mathrm{N}$ & 72 & 72 \\
\cline { 2 - 4 } $\mathbf{M}$ & Rerata & 59,28 & 53,38 \\
\cline { 2 - 4 } & Varians & 539,584 & 530,322 \\
\cline { 2 - 4 } & Minimal & 13 & 13 \\
\cline { 2 - 4 } & Maksima & 100 & 93 \\
& 1 & & \\
\hline
\end{tabular}

Berdasarkan Tabel 5 menunjukkan rata-rata KAM sebelum perlakuan antara kelas eksperimen dan kelas kontrol tidak jauh berbeda. Dapat dilihat pada kelas eksperimen yang akan diberi pembelajaran model kooperatif TPS mempunyai rerata 59,28 dan kelas kontrol yang akan diberi pembelajaran konvensional mempunyai rerata 53,38. Varians kelas eksperimen 
sebesar 539,584 dan varians pada kelas kontrol sebesar 530,322.

Metode yang digunakan dalam mengambil data hasil pada penelitian ini adalah metode tes. Metode tes digunakan untuk mengukur kemampuan awal matematika siswa, kemampuan penyelesaian masalah matematis, dan kemampuan disposisi matematis siswa. Soal tes berupa soal pilihan berganda yang diberikan kepada siswa untuk mengukur kemampuan awal matematika, soal uraian untuk mengukur kemampuan penyelesaian masalah matematis siswa dan angket untuk mengukur kemampuan disposisi matematis siswa.

Setelah data posttest kemampuan penyelesaian masalah dan skor angket disposisi matematis diperoleh, dilanjutkan dengan uji hipotesis data. Langkah-langkah analisis data dalam penelitian ini meliputi: (1) Uji Normalitas menggunakan uji Kolmogorov-Smirnov; (2) Uji Homogenitas menggunakan uji Barlett (3) Uji hipotesis menggunakan uji Anava dua jalur dan Uji t. Semua uji hipotesis tersebut menggunakan bantuan program SPSS-22.

\section{HASIL DAN PEMBAHASAN}

Penelitian ini difokuskan kepada delapan hipotesis penelitian, yaitu: (1) Kemampuan penyelesaian masalah matematika siswa yang diajarkan menggunakan model pembelajaran kooperatif tipe Think Pair Share lebih tinggi daripada siswa yang diajarkan menggunakan model pembelajaran konvensional; (2) Ada interaksi antara model pembelajaran dan kemampuan awal matematika terhadap kemampuan penyelesaian masalah matematika siswa; (3) Kemampuan penyelesaian masalah matematika siswa dengan Kemampuan
Awal Matematika (KAM) tinggi yang diberikan model pembelajaran kooperatif tipe Think Pair Share akan lebih tinggi dibandingkan dengan model pembelajaran konvensional;

(4) Kemampuan penyelesaian masalah matematika siswa dengan Kemampuan Awal Matematika (KAM) rendah yang diberikan model pembelajaran kooperatif tipe Think Pair Share akan lebih rendah dibandingkan dengan model pembelajaran konvensional; (5) Disposisi matematis siswa yang diberikan model pembelajaran kooperatif tipe Think Pair Share lebih tinggi dibandingkan dengan model pembelajaran konvensional; (6) Ada interaksi antara model pembelajaran dan kemampuan awal matematika terhadap penyelesaian masalah matematik; (7) Disposisi matematis siswa yang memiliki kemampuan awal matematika tinggi yang memperoleh model pembelajaran kooperatif tipe think pair share lebih tinggi dibandingkan dengan siswa yang memperoleh pembelajaran konvensional; (8) Disposisi matematis siswa yang memiliki kemampuan awal matematika rendah yang memperoleh model pembelajaran kooperatif tipe Think Pair Share lebih rendah dibandingkan dengan siswa yang memperoleh pembelajaran konvensional.

Data dianalisis menggunakan statistika deskriptif dan statistika inferensial. Data yang dideskripsikan berupa hasil tes akhir kemampuan pemahaman konsep matematika dan kecemasan matematika pada kelas eksperimen dan kontrol. Sebelum menguji hipotesis, data masing-masing kelompok diuji normalitas dan homogenitas terlebih dahulu. Data yang digunakan untuk pengujian tersebut adalah skor kemampuan pemahaman konsep matematika dan skor kecemasan matematika. Hasil uji normalitas 
menggunakan uji Kolmogorov-Smirnov dengan bantuan program SPSS-22 terangkum pada tabel 6 dan tabel 7 berikut ini:

Tabel 6. Uji Normalitas Kemampuan Penyelesaian Masalah Matematika.

\begin{tabular}{cccc}
\hline \multirow{2}{*}{ Model } & \multicolumn{3}{c}{ Kolmogorov-Smirnov } \\
\cline { 2 - 4 } & Statistic & df & Sig. \\
\hline TPS &, 089 & 48 &, $200^{*}$ \\
\hline $\begin{array}{c}\text { Konvensio } \\
\text { nal }\end{array}$ &, 105 & 48 &, $200^{*}$ \\
\hline
\end{tabular}

Tabel 7. Uji Normalitas Skor Disposisi Matematis

\begin{tabular}{lccc}
\hline \multirow{2}{*}{ Model } & \multicolumn{3}{c}{ Kolmogorov-Smirnov } \\
\cline { 2 - 4 } & Statistic & df & Sig. \\
\hline TPS &, 104 & 48 &, $200^{*}$ \\
\hline $\begin{array}{l}\text { Konvensio } \\
\text { nal }\end{array}$ &, 069 & 48 &, $200^{*}$ \\
\hline
\end{tabular}

Hasil perhitungan pada tabel 6 dan 7 menunjukkan bahwa untuk kedua kelompok masing-masing data diperoleh nilai Sig. > 0.05. Dengan demikian dapat disimpulkan kedua kelompok data berasal dari populasi yang berdistribusi normal. Selanjutnya dilakukan uji Homogenitas dengan menggunakan uji Barlett dengan bantuan program SPSS-22 terangkum pada tabel 8 dan tabel 9 berikut ini:

Tabel 8. Uji Homogenitas Kemampuan Penyelesaian Masalah Matematika

\begin{tabular}{cccc}
\hline $\begin{array}{c}\text { Levene } \\
\text { Statistic }\end{array}$ & df1 & df2 & Sig. \\
\hline 2,564 & 1 & 94 &, 112 \\
\hline
\end{tabular}

Tabel 9. Uji Homogenitas Skor Disposisi Matematis.

\begin{tabular}{rrrr}
\hline $\begin{array}{c}\text { Levene } \\
\text { Statistic }\end{array}$ & df1 & df2 & Sig. \\
\hline 1,456 & 1 & 94 &, 231 \\
\hline
\end{tabular}

Hasil perhitungan pada tabel 8 dan 9 menunjukkan bahwa untuk kedua kelompok maisng-masing data diperoleh nilai Sig. > 0.05. Dengan demikian dapat disimpulkan kedua kelompok data memiliki varians yang homogen. Hal ini berarti kemampuan penyelesaian masalah matematika dan disposisi matematis siswa dari kelompok siswa yang mengikuti Think Pair Share dan pembelajaran konvensional memiliki varians yang sama (homogen).

Uji prasyarat menunjukkan masingmasing data normal dan homogen. Selanjutnya dilakukan uji hipotesis untuk mendapatkan data dan mengetahui pengaruh dari model pembelajaran dan KAM. Uji Anava Dua Jalur data hasil kemampuan penyelesaian masalah matematika pada setiap kelompok pembelajaran dimasing-masing kategori kemampuan awal matematika tinggi dan rendah disajikan pada Gambar 1 dan Tabel 10 berikut:

Tabel 10. Uji Anava Dua Jalur Penyelesaian Masalah Matematis

\begin{tabular}{|c|c|c|c|c|}
\hline $\begin{array}{l}\text { Sour } \\
\text { ce }\end{array}$ & $\begin{array}{c}\text { Type } \\
\text { III } \\
\text { Sum } \\
\text { of } \\
\text { Squa } \\
\text { res }\end{array}$ & $\begin{array}{cc} & \text { Mea } \\
& \mathbf{n} \\
\text { d } & \text { Squa } \\
\text { f } & \text { re }\end{array}$ & $\mathbf{F}$ & Sig. \\
\hline $\begin{array}{l}\text { Corr } \\
\text { ected } \\
\text { Mod } \\
\text { el }\end{array}$ & $\begin{array}{r}416,0 \\
42^{\mathrm{a}}\end{array}$ & $\begin{array}{rr} & 138,6 \\
3 & 81\end{array}$ & 20,011 & ,000 \\
\hline
\end{tabular}




\begin{tabular}{|c|c|c|c|}
\hline $\begin{array}{cc} & \text { Type } \\
& \text { III } \\
& \text { Sum } \\
& \text { of } \\
\text { Sour } & \text { Squa } \\
\text { ce } & \text { res }\end{array}$ & $\begin{array}{l}\text { Mea } \\
\text { n } \\
\text { d Squa } \\
\text { f re }\end{array}$ & $\mathbf{F}$ & Sig. \\
\hline $\begin{array}{lr}\text { Inter } & 1485 \\
\text { cept } & 0,375\end{array}$ & 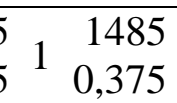 & $\begin{array}{r}2142,83 \\
3\end{array}$ & ,000 \\
\hline MODEL & 48,167 & $\begin{array}{rr}1 & 48,1 \\
& 67\end{array}$ & $\begin{array}{rr}6,9 & , 0 \\
50 & 1 \\
& 0\end{array}$ \\
\hline KAM & 337,500 & $\begin{array}{r}337, \\
500\end{array}$ & $\begin{array}{rr}48, & 0 \\
70 & 0 \\
0 & 0\end{array}$ \\
\hline $\begin{array}{l}\text { MODEL } \\
* \text { KAM }\end{array}$ & 30,375 & $\begin{array}{rr} & 30,3 \\
& 75\end{array}$ & $\begin{array}{rr}4,3 & 0 \\
83 & 3 \\
9\end{array}$ \\
\hline Error & 637,583 & $\begin{array}{rr}92 & 6,93 \\
0\end{array}$ & \\
\hline Total & 15904,000 & 96 & \\
\hline $\begin{array}{l}\text { Correcte } \\
\text { d Total }\end{array}$ & 1053,625 & 95 & \\
\hline
\end{tabular}

Hasil untuk perhitungan ANAVA dua jalur dengan berbantu SPSS 22 di atas menunjukan bahwa nilai sig $0,010<0,05$ maka $\mathrm{H}_{0}$ ditolak, sehingga terdapat perbedaan rerataan yang signifikan kemampuan penyelesaian masalah matematika antara siswa yang mendapatkan pembelajaran dengan model pembelajaran kooperatif TPS dan model pembelajaran konvensional.

Berdasarkan gambar 1 di bawah terlihat bahwa terdapat interaksi antara model pembelajaran dan kemampuan awal matematika terhadap kemampuan penyelesaian matematis. Hal ini ditandai dengan grafik garis yang tidak saling sejajar atau garis tersebut memiliki gradien yang berbeda, maka dapat dikatakan bahwa grafik tersebut memiliki interaksi.

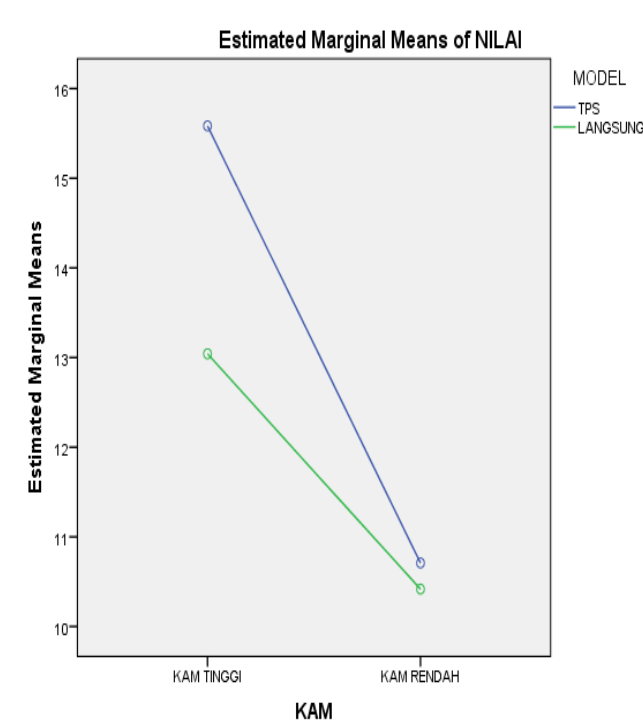

Gambar 1. Interaksi antara Pembelajarandan KAM Terhadap Penyelesaian Masalah Matematika

Berdasarkan hasil perhitungan terlihat bahwa hasil uji-t diperoleh $t_{\text {hitung }}=2,122$. apabila dibandingkan dengan nilai $\mathrm{t}_{\text {tabel }}=$ 1,985. Dengan demikian 2,122 >1,985 maka hipotesis Ho ditolak, sehingga dapat disimpulkan bahwa kemampuan penyelesaian masalah matematika siswa kelompok eksperimen lebih tinggi dari pada kelompok kontrol.

Selanjutnya dilanjutkan dengan uji-t karena terdapat interaksi antara model pembelajaran dan kemampuan awal matematika terhadap kemampuan penyelesaian masalah matematika siswa. Data hasil uji-t hasil kemampuan penyelesaian masalah matematika pada setiap kelompok pembelajaran dimasingmasing kategori kemampuan awal matematika tinggi dan rendah disajikan pada Tabel 11 berikut: 
Tabel 11. Hasil Uji-t Perbedaan

Kemampuan Penyelesaian Masalah pada KAM Tinggi

\begin{tabular}{ccc}
\cline { 2 - 3 } & $\mathbf{t}$ & Sig. \\
\hline $\begin{array}{c}\text { Penyelesaian } \\
\text { Masalah } \\
\text { Matematika }\end{array}$ & 3,127 & 0.003 \\
\hline
\end{tabular}

Berdasarkan hasil perhitungan pada tabel 11 dapat terlihat bahwa hasil uji-t diperoleh $t_{\text {hitung }}=3,127$ pada taraf signifikansi $5 \%$ dengan $\mathrm{dk}=46$ bila dibandingkan dengan $t_{\text {tabel }}=2,013$, sehingga hasil $t_{\text {hitung }} 3,127>2,013=t_{\text {tabel }}$ maka $\mathrm{H}_{0}$ tolak. Hal ini berarti bahwa terdapat perbedaan kemampuan penyelesaian masalah matematika pada siswa yang diajarkan dengan model pembelajaran kooperatif TPS lebih tinggi dibandingkan siswa yang diajarkan dengan model pembelajaran konvensional pada kelompok yang memiliki kemapuan awal matematika tinggi.

Tabel 12. Hasil Uji-t Perbedaan Kemampuan Penyelesaian Masalah pada KAM Rendah

\begin{tabular}{ccc}
\cline { 2 - 3 } & $\mathbf{t}$ & Sig. \\
\hline $\begin{array}{c}\text { Penyelesaian } \\
\text { Masalah } \\
\text { Matematika }\end{array}$ & 0,415 & 0.680 \\
\hline
\end{tabular}

Berdasarkan hasil perhitungan pada tabel 12 dapat terlihat bahwa hasil uji-t diperoleh $\mathrm{t}_{\text {hitung }}=0,415$ dan $-\mathrm{t}_{\text {tabel }}=-2,013$ dan didapat $\mathrm{t}_{\text {hitung }}>-\mathrm{t}_{\text {tabel }}$ maka $\mathrm{H}_{0}$ diterima. Demikian 0,415 > -2,013 maka $\mathrm{H}_{0}$ diterima. Hal ini berarti bahwa tidak terdapat perbedaan kemampuan penyelesaian masalah matematis pada siswa yang diajarkan dengan model pembelajaran kooperatif TPS dibandingkan siswa yang diajarkan dengan model pembelajaran konvensional pada kelompok yang memiliki kemampuan awal matematika rendah.

Selanjutnya Uji Anava Dua Jalur data hasil skor disposisi matematis siswa pada setiap kelompok pembelajaran dimasingmasing kategori kemampuan awal matematika tinggi dan rendah disajikan pada tabel berikut:

Tabel 13. Uji Anava Dua Jalur Disposisi Matematis

\begin{tabular}{|c|c|c|c|c|c|}
\hline Source & $\begin{array}{c}\text { Type } \\
\text { III } \\
\text { Sum of } \\
\text { Squar } \\
\text { es }\end{array}$ & Df & $\begin{array}{l}\text { Mean } \\
\text { Squar } \\
\text { S }\end{array}$ & $\mathbf{F}$ & Sir \\
\hline $\begin{array}{l}\text { Correct } \\
\text { ed } \\
\text { Model }\end{array}$ & $\begin{array}{r}10480, \\
865^{\mathrm{a}}\end{array}$ & 3 & $\begin{array}{r}3493,6 \\
22\end{array}$ & $\begin{array}{r}9,80 \\
9\end{array}$ &, 000 \\
\hline $\begin{array}{l}\text { Interce } \\
\mathrm{pt}\end{array}$ & $\begin{array}{r}913185 \\
, 094\end{array}$ & 1 & $\begin{array}{r}913185 \\
, 094\end{array}$ & $\begin{array}{r}256 \\
3,94 \\
9\end{array}$ & ,000 \\
\hline $\begin{array}{l}\text { MODE } \\
\mathrm{L}\end{array}$ & $\begin{array}{r}2635,5 \\
10 \\
\end{array}$ & 1 & $\begin{array}{r}2635,5 \\
10 \\
\end{array}$ & $\begin{array}{r}7,40 \\
0 \\
\end{array}$ & ,008 \\
\hline KAM & $\begin{array}{r}5475,2 \\
60 \\
\end{array}$ & 1 & $\begin{array}{r}5475,2 \\
60 \\
\end{array}$ & $\begin{array}{r}15,3 \\
73 \\
\end{array}$ & ,000 \\
\hline $\begin{array}{l}\text { MODE } \\
\text { L* } \\
\text { KAM }\end{array}$ & $\begin{array}{r}2370,0 \\
94\end{array}$ & 1 & $\begin{array}{r}2370,0 \\
94\end{array}$ & $\begin{array}{r}6,65 \\
5\end{array}$ & ,011 \\
\hline Error & $\begin{array}{r}32767, \\
042 \\
\end{array}$ & 92 & $\begin{array}{r}356,16 \\
3 \\
\end{array}$ & & \\
\hline Total & $\begin{array}{r}956433 \\
, 000 \\
\end{array}$ & 96 & & & \\
\hline $\begin{array}{l}\text { Correct } \\
\text { ed } \\
\text { Total }\end{array}$ & $\begin{array}{r}43247, \\
906\end{array}$ & 95 & & & \\
\hline
\end{tabular}

Berdasarkan Tabel 13 hasil perhitungan ANAVA dua jalur dengan berbantu SPSS 22 di atas menunjukan bahwa nilai sig 0,008 kurang dari 0,05. Hal ini berarti bahwa $\mathrm{H}_{0}$ ditolak, sehingga terdapat perbedaan rerata yang signifikan disposisi matematis siswa antara yang mengikuti pembelajaran dengan model 
pembelajaran kooperatif TPS dan model pembelajaran konvensional.

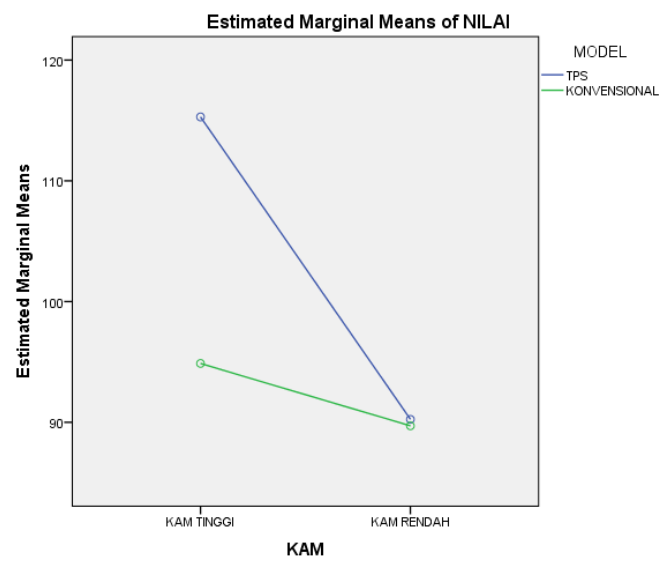

Gambar 2. Interaksi antara Pembelajarandan KAM Terhadap Disposisi Matematis

Berdasarkan Gambar 2 di atas terlihat bahwa interaksi antara model pembelajaran dan KAM terhadap disposisi matematis. Hal ini ditandai dengan grafik garis yang tidak saling sejajar atau garis tersebut memiliki gradien yang berbeda, maka dapat dikatakan bahwa grafik tersebut memiliki interaksi.

Selanjutnya dilanjutkan dengan uji-t karena terdapat interaksi antara model pembelajaran dan kemampuan awal matematika terhadap disposisi matematis siswa. Data hasil uji-t hasil skor disposisi matematis pada setiap kelompok pembelajaran dimasing-masing kategori kemampuan awal matematika tinggi dan rendah disajikan pada tabel berikut:

Tabel 14. Uji-t Disposisi Matematis dengan KAM Tinggi

\begin{tabular}{ccc} 
Kemampuan & $\mathrm{t}$ & Sig. \\
\hline $\begin{array}{c}\text { Disposisi } \\
\text { Matematis }\end{array}$ & 3,249 & 0.002
\end{tabular}

Berdasarkan hasil perhitungan pada Tabel 14 dapat terlihat bahwa hasil uji-t doperoleh $\quad t_{\text {hitung }}=3,249$ pada taraf signifikansi $=0,05$ bila dibandingkan $\mathrm{t}_{\text {tabel }}=$ 2,013 sehingga hasil $t_{\text {hitung }}=3,249>2,013$ $=\mathrm{t}_{\text {tabel }}$ maka $\mathrm{H}_{0}$ ditolak. Hal ini berati bahwa terdapat perbedaan disposisi matematis pada siswa yang diajarkan dengan model kooperatif TPS dengan siswa yang diajarkan dengan model konvensional pada kelompok yang memiliki KAM tinggi. Berdasarkan hasil menunjukan bahwa disposisi matematis siswa yang diberi perlakuan pembelajaran Kooperatif TPS lebih tinggi dibandingkan siswa yang diberi pembelajaran konvensional pada kelompok yang memiliki KAM tinggi.

Tabel 15. Uji-t Disposisi Matematis dengan KAM Rendah

\begin{tabular}{ccc}
\hline Kemampuan & $\mathbf{t}$ & Sig. \\
\hline $\begin{array}{c}\text { Disposisi } \\
\text { Matematis }\end{array}$ & 0.122 & 0.944 \\
\hline
\end{tabular}

Berdasarkan hasil perhitungan pada tabel 15 dapat terlihat bahwa hasil uji-t diperoleh $t_{\text {hitung }}=0,122$ dan $-t_{\text {tabel }}=-2,013$ karena hasil kriteria tolak $\mathrm{H}_{0}$ adalah $\mathrm{t}_{\text {hitung }}<-\mathrm{t}_{\text {tabel }}$ dan didapat $\mathrm{t}_{\text {hitung }}>-\mathrm{t}_{\text {tabel }}$ maka $\mathrm{H}_{0}$ diterima pada taraf signifikansi $5 \%$. Hal ini berarti bahwa tidak terdapat perbedaan disposisi matematis pada siswa yang diajarkan dengan model pembelajaran kooperatif TPS dibandingkan siswa yang diajarkan dengan model pembelajaran konvensional pada kelompok yang memiliki kemampuan awal matematika rendah.

\section{SIMPULAN}

Berdasarkan hasil penelitian dan pembahasan menunjukkan bahwa (1) kemampuan penyelesaian masalah siswa yang belajar menggunakan model kooperatif TPS lebih tinggi daripada model 
pembelajaran konvensional,

terdapat interaksi antara model pembelajaran dan kemampuan awal matematika terhadap kemampuan penyelesaian masalah matematis siswa, (3) terdapat perbedaan kemampuan penyelesaian masalah matematis antara siswa dengan kemampuan awal matematika tinggi yang belajar dengan model kooperatif TPS dan model pembelajaran konvensional, (4) Tidak terdapat perbedaan kemampuan penyelesaian masalah matematika siswa dengan kemampuan awal matematika rendah, antara yang mendapatkan model pembelajaran kooperatif TPS dengan model pembelajaran konvensional; (5) disposisi matematis siswa yang belajar dengan model pembelajaran kooperatif TPS lebih tinggi dari pada model pembelajaran konvensional, (6) terdapat interaksi antara model pembelajaran dan kemampuan awal matematika terhadap disposisi matematis siswa, (7) terdapat perbedaan kemampuan disposisi matematis antara siswa dengan kemampuan awal matematika tinggi yang belajar dengan model pembelajaran kooperatif TPS dan model pembelajaran konvenisonal, (8) Tidak terdapat perbedaan disposisi matematis siswa dengan kemampuan awal matematika rendah, antara yang mendapatkan model pembelajaran kooperatif tipe TPS dengan model pembelajaran konvensional.

\section{DAFTAR PUSTAKA}

Arends, Richard I. 2007. Learning To Teach. New York: Mc Graw Hill Companies.

Chianson, Mimi Martha, O’kwu, Ijenkeli Emmanuel, Kurumeh, Mary Seraphina. 2015. "Effect Of Think-Pair-Share Strategy On Secondary School Mathematics Students' Achievement And Academic Self-Esteem In Fractions.” AIJCSR. Vol. 2(2), pp:141147.

Cooke, Audrey. 2015. "Considering Pre-service Teacher Disposition towards Mathematics." Mathematics Education Research Group of Australasia, Inc. Vol. 17 (1), pp:1-11.

Hamdayana, Jumanta. 2014. Model dan Metode Pembelajaran Kreatif dan Berkarakter. Bogor: Ghalia Indonesia.

Jonassen, D.H. \& Grabowski, B.L. 1993. Handbook of individual differences, learning, and instruction. Part VII, Prior knowledge. Hillsdale: Lawrence Erlbaum Associates.

Kadir. 2010. Statistika Untuk Penelitian Ilmu-ilmu Sosial. Jakarta: Rosetama Sampurna.

Kilpatrick, J., Swafford, J., \& Findell, B. 2001. Adding It Up: Helping Children Learn Mathematics. Washington, DC: National Academy Press.

Kurniasih, Imas dan Sani, Berlin. 2015. Ragam Pengembangan Model Pembelajaran Untuk Peningkatan Profesionalitas Guru. Yogyakarta: Kata Pena. 
Memnum, Dilek Sezgin,. Hart, Lynn C., \& Akkaya Recai. 2012 "A Research on the Mathematical Problem Solving Beliefs of Mathematics, Science and Elementary PreService Teachers in Turkey in Terms of Different Variables." International Journal of Humanities and Social Science. Vol 2 (24), pp:172-184.

NCTM. 1989. Curriculum and Evaluation Standars for School Mathematics. Reston, VA: NCTM.

Peraturan Menteri Pendidikan Nasional Nomor 22 Tahun 2006 Tentang Standar Isi Untuk Satuan Pendidikan Dasar dan Menengah. Jakarta: Permendiknas.

PISA. 2012. PISA 2012 Result in Focus, What 15-Year-Olds Know and What They Can do With What They Know. Paris: The Organitation for Economic Co-operation and Development Publications.

Polya, G. 2004. How to Solve It. Princeton: Princeton University Press.

Reigeluth, C. M. 1999. Instructional Design Theories and Models. London: Lawrence Erlbaum.

Sujarweni, V Wiratna. 2014. SPSS Untuk Penelitian. Yogyakarta: Pustaka Baru Press.

Sumarmo, Utari. 2012. Bahan Belajar Matakuliah Proses Berpikir Matematika. Bandung: Program S2 Pendidikan Matematika STKIP Siliwangi.

. 2012. Pendidikan Karakter Dan Pengembangan Kemampuan Berpikir Dan Disposisi Matematik Serta Pembelajarannya. Bandung: Jurusan Pendidikan Matematika Fakultas Pendidikan MIPA UPI.

TIMSS. 2011. TIMSS 2011 International Result In Mathematics. Boston: TIMSS \& PIRLS International Study Center, 5-48.

Tint, San San \& Ei Ei Nyunt. 2015. "Collaborative Learning With Think-Pair-Share Technique.” Computer Applications: An International Journal (CAIJ). Vol 2 (1), pp: $1-11$.

Turmudi. 2008. Landasan Filsafat dan Teori Pembelajaran Matematika (Berparadigma Eksploratif dan Investigatif). Jakarta: PT Leuser Cita Pustaka.

White, Dorothy Y. Eileen C. Murray Victor Brunaud-Vega. 2012. "Discovering Multicultural Mathematics Dispositions." Journal of Urban Mathematics Education. Vol. 5 (1), pp: 31-43. 
FIBONACCI : Jurnal Pendidikan Matematika dan Matematika

Volume 4 No.2 Bulan Desember Tahun 2018 